Daniel H. Weiss

University of Cambridge

\title{
Aquinas's opposition to killing the innocent and its distinctiveness within the Christian just war tradition
}

\author{
(forthcoming in Journal of Religious Ethics)
}

\section{$\underline{\text { Introduction }}$}

Most accounts of the Christian just war tradition assume a basic historical continuity with regard to the question of causing the death of innocents in warfare. Specifically, it is assumed that from Augustine onward, and with Aquinas as a notable point along the way, the death of innocents is something that should be avoided if at all possible, but that it can sometimes be a necessary, if tragic, component of carrying out a just war. Often, emphasis is placed on a prohibition against intentionally causing the death of innocents. While such intentional killing is held to be unqualifiedly prohibited, actions that cause innocent deaths in a 'foreseen yet nonintended' manner can nevertheless be a legitimate part of just war.

Here, however, I will argue that in context of this historical just war tradition, Aquinas's position marks a sharp discontinuity with regard to causing the death of innocents. While Aquinas does indeed uphold the possibility of just war, his broader account of the inviolability of innocent life nevertheless strongly indicates that it is inherently unlawful and illegitimate to cause the death of innocents in a foreseen or foreseeable manner, regardless of whether that killing is 'intended' or 'non-intended.' For Aquinas, only sinners or evildoers can be legitimately killed, and he unqualifiedly holds that "[t]here is, therefore, simply no justification for taking the life of an innocent person” (Summa Theologiae [hereafter ST] II-II, q. 64, a. 6). ${ }^{1}$ For Aquinas, because God retains authority over life and death, there is no greater good or goal, whether in war or otherwise, that could justify causing the death of innocents. As we shall see, however, this claim concerning Aquinas's position has not been widely recognized within existing scholarship, even though even though there have also not been substantive scholarly arguments made against it.

In order to highlight Aquinas's distinctiveness, I first discuss the way in which Augustine's position does leave space for the legitimacy of killing of innocents in war. With this in mind, I then turn to Aquinas's own position, showing the various ways in which he expresses his opposition to causing the death of innocents. I first examine his statements with regard to intra-societal killing by public authorities and killing in self-defense, in which the prohibition of causing the non-intended death of innocents is strongly upheld. I then turn to his discussion of warfare, in which this prohibition appears to be in no way lessened. Subsequently, I look at the way in which Aquinas's subsequent inheritors in the just war tradition, while in many ways attempting to align themselves with Aquinas's language and formulations, nevertheless diverge from Aquinas's position. As such, within the broader tradition, Aquinas appears to represent a unique but significant conception of just war vis-à-vis the lives of innocents, a position with radical ethical and practical implications for the actual carrying out of warfare. Because this stance breaks so sharply with many if not most other instances of historical and contemporary

\footnotetext{
${ }^{1}$ All English translations drawn from Aquinas 1964-1980.
} 
just war thinking, a clearer understanding of it can contribute to challenging prevailing assumptions in the debate between pacifist and just war orientations.

Before commencing, a few brief methodological comments are in order. As we shall see, Aquinas does not make any explicit statements about the permissibility or the impermissibility of wartime killing of innocents. As such, in seeking to explore this question, the argument I present is built up from his more general comments about the killing of innocents, about the relation of foresight to permissible actions, and about the connection between warfare and the punishment of evildoers. I will argue that, taken together, these elements can be most plausibly understood as part of a coherent conceptual framework in which causing the death of innocents in a foreseeable yet unintended manner remains prohibited even in the context of war. Yet, even if Aquinas's own stated thought appears to point strongly in this direction, this in turn raises the question of whether Aquinas could really have ruled out such causing of innocent death in war, as this restriction could appear to make warfare as such impossible to carry out. Accordingly, after looking at the textual evidence for Aquinas's conceptuality, I will also give attention to the thirteenth-century practices of war, and I will consider whether 'war without causing the death of innocents' could have been a realistically conceivable possibility in Aquinas's historical context. In this regard, I will argue that, although it may seem to us today to be a practical impossibility and hence an unrealistic conception, it would indeed have been historically possible for Aquinas to hold such a view, and as such the textual evidence for his conceptual stance ought to be taken seriously.

\section{$\underline{\text { Augustine’s legitimation of killing innocents in war }}$}

Of Christian thinkers prior to Aquinas, the most prominent expositor of Christian approaches to killing in war is Augustine. For the sake of my argument here, I primarily want to emphasize that Augustine does not put forth a categorical rejection of actions in war that knowingly cause the death of innocents. Rather, while he may put forth admonitions that seek, as a general guiding principle, to safeguard innocents, he also seems clearly to allow for military actions that, in today's terminology, would cause the death of innocents in an 'indirect' yet still foreseen and anticipated manner. To demonstrate this point, it is useful to examine two prominent competing interpretations of Augustine on the question of the death of innocents in war, namely, those of Richard Hartigan and Paul Ramsey. ${ }^{2}$ While their respective readings disagree on a number of issues, they nevertheless agree that Augustine does permit, at the very least, such forms of 'indirect' killing of innocents in war.

Richard Hartigan has pointed to Augustine's general emphasis on inward motivation in determining the rightness or wrongness of a certain action (see Hartigan 1966; also Hartigan 1982). As regards war in particular, Augustine's often-quoted statement from his Contra Faustum (22:4; translation from Augustine 1994, 301) speaks to this orientation:

What is the evil in war? Is it the death of some who will soon die in any case, that others may live in peaceful subjection? This is merely cowardly dislike, not any religious feeling. The real evils in war are love of violence, revengeful cruelty, fierce and implacable enmity, wild resistance, the lust of power, and such like; and it is generally to punish these things, when force is required to inflict the punishment, that, in obedience to God or some lawful authority, good men undertake wars.

\footnotetext{
${ }^{2}$ For a comparative assessment of these two thinkers' approach to Augustine and war, see Stevenson 1987, 110ff.
} 
Here, the outward fact of one person being killed by another is not inherently unethical, as all people will eventually die in the not-so-distant future, and so the mere phenomenon of death is not viewed as a problematic deviation from the natural order of this world. What would make an act of causing death in war problematic is if such killing was done from out of immoral motivations, such as cruelty, desire for power, hatred, etc. The implication is that if killing can be done in a way that does not involve such personal vices and passions, then that killing can be morally acceptable and legitimate. For Augustine, war provides a context in which such dispassionate killing can occur: the virtuous military commander who orders the killing to take place does so not out of any individual motivation of passion, but for the sake of restoring justice, preserving the good of the public order, and justly punishing wrongdoers. Likewise, a virtuous soldier who kills in war can also do so dispassionately, since he is simply acting out of duty in fulfilling the orders of his commander; his acts of military violence do not stem from any personal desire to kill, and so the act of killing is not morally blameworthy.

Hartigan emphasizes that in the context of this framework, Augustine frames his evaluation in connection to the inner state of the person doing the killing, and does not treat the innocence or guilt of the person killed as playing a morally significant role: "The innocence or guilt of those attacked is of no consequence in determining the guilt of the attacker; the only factors which constrain him are the subjective ones of his own intent and his estimation of military necessity. Any objective determination as to who are innocent or guilty among the enemy is not only impossible but is also irrelevant” (Hartigan 1966, 203). Thus, in Hartigan’s account of Augustine, while one should in principle seek to punish only evildoers, and one should in principle seek to protect the lives of innocents, one should not refrain from engaging in a just military campaign simply because it may inadvertently involve the death of innocents in the process of the broader effort to uphold justice and establish peace. As long as the proper motivation is driving the actions, the fact that the actions may also entail causing the death of innocents does not invalidate the actions themselves. ${ }^{3}$

While Hartigan sees Augustine as setting aside as irrelevant the question of guilt or innocence of those who are killed a justly motivated war, Paul Ramsey, by contrast, sees Augustine as a progenitor of the later concept of noncombatant immunity (Ramsey 1961, 34-39). Rather than focusing on the contrast between inward motivation and outward action, Ramsey emphasizes the importance of the Christian norm of love. In his view, while Augustine does not explicitly affirm the protection of the innocent in a framework of jus in bello, he nevertheless affirms "a difference between killing an unjust aggressor and killing the innocent” (Ramsey 1961, 36). He likewise emphasizes that the "protection of citizens" plays a fundamental role in Augustine's thinking (Ramsey 1961, 38). Drawing on these principles, but again without an explicit basis in Augustine's texts, Ramsey suggests that Augustine can be seen as viewing war as stemming from a motive of Christian love, seeking to prevent injustice from being committed (Ramsey 1961, 38; see also Ramsey 2002, 206-207). In Ramsey’s account of Augustine, the principle of love would remain in force even when engaging in war, and a virtuous military commander, as well as a virtuous soldier, must continue to uphold their commitment to protect innocents and to direct one's just violence only at aggressors. In this portrayal, Augustine's norm of love already represents an implicit commitment to the safety of noncombatants, and thus the later development of noncombatant immunity can be seen as drawing out more explicitly what was already latent in Augustine's approach.

\footnotetext{
${ }^{3}$ See also Hartigan 1982, 33: "Those who kill while prosecuting a just war are condemned by Augustine only if they do so from a motive of private passion, or if they continue to slay when it is no longer necessary."
} 
It is notable that Ramsey has difficulty in finding explicit textual support in Augustine for the principle of protection of innocents in war, and needs to argue mainly by way of extrapolation. Yet, even if we were to accept his presentation of Augustine as setting the stage for the notion of noncombant immunity, Ramsey simultaneously makes clear that such an approach need not rule out causing the death of innocents in war. Rather, what Ramsey views as ruled out by the principle of love is specifically the 'direct' causing of death. In discussing the broader history of the concept of noncombatant immunity, he writes, "It was never supposed that non-combatants were immune from all damage but only from direct, intended attack" (Ramsey 2002, 145-146, italics added). Instead, in the ethical framework that he has in mind, "A desired and desirable victory may, however, justify conduct in warfare that causes the death, and is foreseen to cause the death, of non-combatants indirectly" (Ramsey 2002, 154, italics in the original). Thus, while many forms of killing innocents remain forbidden, the notion that Ramsey seeks to link to Augustine would still allow a person knowingly to cause the death innocents in a just war, so long as the actions were deemed to be militarily necessary for executing a war that is in itself judged to be a just one. While such killing would, importantly, be a tragic necessity, arising from the tension between the duty of love and concern for innocents and the duty to establish just order, it would nevertheless be an ethically legitimate form of killing.

Both Hartigan and Ramsey highlight important aspects of Augustine's thought.

Augustine undoubtedly places a strong emphasis on inward intention, as Hartigan maintains, and he also places a strong emphasis on love and concern for others, as Ramsey argues. My purpose here is not to adjudicate decisively between Hartigan and Ramsey, but rather to point out that there is an important practical overlap in their two portrayals of Augustine: if a justly-motivated war can be carried out only by engaging in actions that knowingly lead to the death of innocents, then both Hartigan's Augustine and Ramsey's Augustine would deem such actions to be ethically legitimate. While Hartigan argues that the guilt or innocence of those killed is in itself irrelevant, Ramsey would say that a potential victim's innocence does play an important role in principle, but that such concern nevertheless can be 'outweighed' by the competing principle of the need for victory in a war aimed at re-establishing order and justice. Put differently, in neither interpretation would Augustine say that the knowingly but indirectly causing the death of innocents makes a military action ethically illegitimate. In short, for Augustine, the effort to maintain order and basic justice is necessarily messy, and as long proper intention is upheld, one should engage in war even at cost of innocent life, rather than refrain from war in order to avoid causing the death of innocents.

\section{Aquinas's distinctive rejection of 'killing innocents with foreknowledge'}

It is on this latter point that Aquinas marks a significant departure from the Augustinian position towards the killing of innocents. For Aquinas, it is not simply intending or 'directly' causing the death of innocents that would make an action illegitimate. Rather, he imposes a further restriction through the category of foreknowledge: an action that foreknowingly causes the death of innocents can never be legitimate, regardless of whether that action causes death 'directly' or 'indirectly.' However, this aspect of Aquinas's approach been less frequently noted, and so the difference of his approach both from his precursors such as Augustine, and from his inheritors in the Christian just war tradition such as Cajetan and Vitoria, has likewise tended to be overlooked by scholars. Thus, I will present the basic reasons why, for Aquinas, foreknowledge (whether of certainty or even mere probability) makes the killing of innocents 
inherently unethical and illegitimate, before going on to indicate the ways in which Aquinas's successors in the tradition did not preserve this key aspect of Aquinas's thought but instead reverted back to a functionally ‘Augustinian’ position.

In relation to previous scholarship, it is important to emphasize that while many have overlooked this aspect of Aquinas's thought, there are a few scholars who have in fact highlighted this important element. ${ }^{4}$ Yet, I have also not been able to find any scholarly arguments made against this claim. That is, there do not seem to be any scholars who have acknowledged the possibility that Aquinas's thought is incompatible with causing the death of innocents in war and have then gone on to argue against it. Rather, the very idea seems simply to have been largely unaddressed and ignored. While the reasons for this neglect in treatments of Aquinas are not fully clear, and while I will argue that his stance is remarkably straightforward and consistent, it is true that Aquinas does not make any explicit statements one way or another about causing the death of innocents in war. This may then have left space for different scholars to read or misread him in light of their assumption of his continuity with other Christian just war thinkers.

These problematic readings tend to take a few different forms. In some cases, it is simply assumed, without citing any textual evidence, that Aquinas's justification of killing an aggressor in self-defense extends straightforwardly within Aquinas's understanding to killing the innocent in war. Thus, Richard Hartigan, while noting that there is no explicit justification in Aquinas of causing the death of innocents, nevertheless argues that Aquinas took for granted the legitimacy of such actions and so did not need to discuss them explicitly (Hartigan 1982, 44). Extrapolating (without apparent justification) from Aquinas's account of self-defense, Hartigan writes that "what Thomas intends to prohibit is the direct or intentional killing of the innocent. Therefore accidental or unintended death is not sinful” (Hartigan 1982, 48). In a second scholarly variation, as, for example, in T.A. Cavanaugh's treatment, one can find acknowledgment that Aquinas does not provide any explicit application of 'double effect' reasoning to justifications of killing in war. Yet, such scholarly accounts still tend to assume a basic compatibility between Aquinas's thought and the foreseen yet unintended killing of innocents, and do not recognize that such a notion in fact stands in direct contradiction to Aquinas's basic principles (see Cavanaugh 2006, 2, 17-20, 28). Again, such accounts tend to ignore key textual passages such as Aquinas's treatment of the parable of the wheat and the tares, to be discussed below. Finally, a third permutation is exemplified in Bernard Adeney, who assumes that Aquinas would affirm that legitimacy of unintentional killing of innocents in war, and who explains the absence of explicit statements to that effect by positing that "it was unlikely that, with the limited war technology of the thirteenth century, 'innocent' bystanders would be killed as an unintended side effect" (Adeney 1988, 39). In other words, and again without addressing the relevant texts, he sees no reason to think that Aquinas would oppose such killing on principled grounds, but thinks that he omitted mention of it simply because had no occasion, due to his historical context, to address it explicitly. Accordingly, addressing later thinkers who do explicitly affirm causing the death of innocents in war, Adeney goes on to state, "Vittoria [sic] and Suarez extended Aquinas' double effect doctrine and allowed killing the innocent when it is an unavoidable side effect." (Adeney 1988, 43). Rather than seeing this position as a fundamental conceptual departure from Aquinas, it is presented simply as a natural 'extension' of his account.

\footnotetext{
${ }^{4}$ See Bell 2009, 213-219; Montaldi 1986; Walters 1971, 159-162, 197-199. However, these studies do not provide as extensive an analysis of this element of Aquinas's thought, and do not place as much focus on the distinctiveness of Aquinas in this regard in the broader just war tradition.
} 
In contrast to such approaches, I will first show that a prima facie examination of Aquinas's thought in Summa Theologiae indicates that the notion of knowingly causing the death of innocents in war stands in conceptual contradiction to Aquinas's stated views. I also show that Aquinas's account of killing in self-defense does not, in fact, carry over to indirect killing of innocents, whether in war or otherwise. The combined upshot of these two elements is that Aquinas's stance represents a radical protection of innocent life, thus calling into question the legitimacy of many, though not necessarily all, forms of practiced warfare both ancient and modern. Importantly, much of what Aquinas says about causing the death of innocents is not explicitly applied by him to the context of warfare. However, the passages that I examine below are presented by him in terms of general ethical-legal principles, and would accordingly seem to be relevant to the ethical context of warfare as well, unless Aquinas explicitly indicates otherwise - which, in the case of these matters, he does not. Thus, methodologically, if someone wanted to argue that Aquinas's prohibition on causing the foreseeable yet unintended death of innocents applied only to situations of non-warfare but not to situations of warfare, the burden of proof would be on the person who sought to limit the scope of Aquinas's stated principles, rather than the other way around.

Aquinas states straightforwardly, "A man can be looked at in two ways - in isolation and in some context. Now, considering every man in isolation, it is not legitimate to kill any man. Every man, even the sinner, has a nature which God made, and which as such we are bound to love, whereas we violate it by killing him. It nevertheless remains true...that sin corrodes the common good and so justifies the killing of the sinner, where the life of just men preserves and promotes the common good, since they constitute the bulk of the people. There is, therefore, simply no justification for taking the life of an innocent person (Et ideo nullo modo licet occidere innocentem)" (ST II-II, q.64, a.6). Here, the contrast between a sinner and an innocent person is crucial. In the case of a sinner, although there are some circumstances in which slaying a sinner is not lawful (see ST II-II, q. 64, a.2), Aquinas states here that there are certain circumstances specifically, in seeking to prevent "corruption of the common good" - in which slaying a sinner is lawful. And, it is specifically the sinful action of the transgressor that transfers him to the category of 'legitimately killable'. By contrast, there are no circumstances in which slaying the innocent can advance the common good, and hence it is never legitimate to slay the innocent. Aquinas's assertion is stated in clear and categorical terms, and does not appear to leave room for any exceptions. ${ }^{5}$

Furthermore, because many have sought to justify the death of innocents in war by distinguishing between 'directly intended deaths' and 'deaths that are foreseen but not intended', it is important to emphasize that, for Aquinas, a person is guilty of illegitimate homicide if he or she engages in action that can be foreseen to cause the death of another person, even if that death is not directly intended by the agent. In discussion of "somebody who kills another by accident," Aquinas states, "What is not willed or intended as such may nevertheless be incidentally willed or intended. We may incidentally cause something by removing the obstacle against that thing happening. It follows that somebody who does not remove such occasions of homicide as he could and should remove will in some way be guilty of voluntary homicide...if a man engages in legitimate activities and uses due care, he is not guilty of any homicide that may ensue; if, on the other hand, he engages in illicit activities, or even fails to take due care in some legitimate enterprise, he is guilty of any homicide that may occur (non evadit homicidii reatum)" (ST II-II,

\footnotetext{
${ }^{5}$ The exception noted in ST II-II, q. 64, a.6, that one can kill the innocent if God commands it, will be discussed further below.
} 
q.64, a.8). Here, Aquinas distinguishes between two types of actions that result in the 'unintentional' death of another person. If a person 'takes due care' in his or her actions and yet nevertheless the action results in the death of another, the agent is not guilty of illegitimate homicide. In other words, if a person is chopping down a tree in a isolated forest, in which hardly anyone ever passes by, and if she also looks around carefully before chopping down the tree, then if it happens by chance that another person previously hidden from view had at that moment walked by quietly and was killed by the falling tree, the first person would not be guilty of illegitimate homicide. In such a scenario, the agent had taken due care, and had no reason or basis to foresee that her action would cause the death of another.

By contrast, if a person is chopping down a tree in a residential neighborhood, and does not take due care to make sure that no one is in the vicinity, then if the falling tree kills a passerby, the agent is guilty of illegitimate homicide. The agent cannot claim, "My intention was simply to chop down the tree, a purely lawful activity in itself; I had no intention of killing anybody." Because the agent, in that situation, should rightly have known that death could be a likely result of chopping down the tree, she is, in Aquinas's view, liable for the 'non-intended' death. Note that in this scenario, the agent is liable even when the problematic action is merely a failure to take due care. We do not need to assume that the agent knew that such a death was likely to result, but simply that she should have known that death was a likely result of that action in that situation. That is, it was a situation which a reasonable person would recognize as one in which death could be a likely result. As such, if liability holds even without presuming the agent's conscious awareness of the danger, an agent would be liable a fortiori in a situation in which she was consciously aware that the action could likely cause death, and yet engaged in the action nevertheless. Thus, for Aquinas, because an agent who causes death in an unintended yet foreseen (or foreseeable) manner is guilty of homicide, it is illegitimate, $a b$ initio, to engage in an action that you foresee will likely result in the death of an innocent person, regardless of whether you 'directly intend' the death of that person.

Aquinas's stance on foreseen but unintended killing is further reinforced by his more general comments in ST I-II, q.20, a.5, on whether foreseen or foreseeable consequences can increase the moral good or evil of a particular action. There, he emphasizes that a foreseen or foreseeable consequence of a certain action can add to the 'moral bad' of an action, and that acting despite such foreseen consequences can make it into a punishable one. Aquinas writes, "That a person thinks (cogitate) of the evil consequences that can follow, and nevertheless does not on this account does not refrain from doing it is clear evidence how much the more his will is disordered." 6 Thus, a person may have perfectly proper intentions motivating her action, and may have a perfectly proper end as the object of her will, but if the person foresees, or could foresee, that an evil consequence (e.g., causing the death of an innocent person) is likely to result, she ought to refrain from the action. If she goes ahead anyway, having thought beforehand of the likely consequence, she would be liable for punishment for the consequence that has been brought about. Thus, having right ends in mind and right intentions is not sufficient to make a foreseen killing legitimate; on the contrary, engaging in such an action despite the foresight simply underscores the disorder of the will entailed in the action. In this regard, Aquinas can be viewed as standing in contrast to Augustine, who, as we saw above, tended to attribute the good or evil of an action to the agent's intentions or passions, and who

\footnotetext{
${ }^{6}$ Cf. Anscombe's $(2001,65)$ citation of this passage in connection to her criticism of those who seek to ascribe the Doctrine of Double Effect to Aquinas.
} 
tended to neglect the moral significance of the external consequences that are foreseeably caused by the action. ${ }^{7}$

It is true that some have pointed to Aquinas's account of killing in self-defense as a basis for justifying foreseen yet unintentional killing of innocents in war. However, the most straightforward reading of Aquinas's presentation in this section (ST II-II, q.64, a.7) would appear to indicate that he is specifically legitimating the killing of an unjust and sinful attacker, and that his statements would not extend to the killing of an innocent person. The reason that Aquinas, in this section, raises questions of effects that are intended and effects that are not intended is due to his distinction between private individuals and public persons. Aquinas had stated earlier in ST II-II, q. 64, a.2 that only public officials, to whom care of the common good is entrusted, have the right to kill sinners. By contrast, private individuals do not, as a rule, have the right to kill sinners - even if an attacker, by his actions, has rendered himself in-principle killable. Instead, private individuals are to leave the killing of such sinners to public officials. For their own part, as stated in ST II-II, q. 64, a.3, private individuals can contribute to the common good only through actions that do not harm others; in the case of an action that would cause the death of another, even if such an action would appear to contribute to the common good, and even if the person killed is an apparent sinner, the private individual must nevertheless refrain engaging in such an action.

The question of self-defense therefore represents a borderline scenario. If, as a rule, a private individual must refrain from killing evildoers, does that mean that a private individual cannot kill an evildoing attacker, even in self-defense? The tension arises because, on the one hand, the aggressor is a sinner and therefore falls into the category of those who can be legitimately killed - but, on the other hand, it is normally only public authority who would have the right to engage in such killing. Aquinas holds that, in the case of self-defense, a private individual is permitted to engage in actions that cause the death of the sinful attacker, if that is the only way that the attack can be prevented. He reconciles this permission with his general prohibition on the killing of sinners by private individuals by making recourse to the notion of intention. If, in acting to repel the attack, the individual intends simply to ward off the attack, then the action can remain legitimate even if that action also has the 'unintended' effect of causing the death of the attacker. However, if in acting to repel the attack, the individual acts from an intentionto kill the attacker, then the individual has illegitimately moved into a sphere of action that is permissible only for public authorities. Thus, in the case of self-defense, the same outward act can be legitimate or illegitimate, depending on the intention behind the act.

At first glance, Aquinas's appeal to intention could appear similar to Augustine's prioritization of inner state over outward act. However, a key element in the case of Aquinas is that the question of intention comes into play only in the case of causing the death of an evildoer or sinner. We have already seen (ST II-II, q.64, a.6) that evildoers can sometimes be legitimately killed, but that the innocent can never be killed. That is, the question of legitimate killing is already restricted specifically to the domain of evildoers or sinners. Within this domain, however, there are further restrictions: while a public official can, in appropriate scenarios, kill an evildoer for the sake of the common good, a private individual is more limited, and can engage in actions that cause the death of an evildoer only when warding off an aggressor's attack, and furthermore only when the action is performed specifically with the intention of warding off the attack and not with the intention of causing the death of the aggressor. Thus, for

\footnotetext{
${ }^{7}$ Aquinas's departure from Augustine in this regard may be linked in part to the influence of Aristotle. Cf. Cooper 2013, 297-298.
} 
Aquinas, there are situations where 'proper intention' is required for legitimate killing - but such situations are specifically ones involving the killing of an evildoer. In other words, for killing to be legitimate, it requires not only a specific intention on the part of the agent, but also a specific status of the person killed - namely, it requires that the person to be killed is a sinner and aggressor and not an innocent person. By contrast, if a person is innocent, then it is always illegitimate to cause the death of that person in a foreseeable manner, regardless of whether the causing of death is intentional or non-intentional, and regardless of whether the agent is a private individual or a public official. If a person's status is innocent rather than sinful, this status cuts away the relevance of intention and illegitimizes all acts of causing that person's death. ${ }^{8}$ Thus, while many contemporary ethicists qualify the prohibition on killing the innocent by speaking specifically of a prohibition on 'direct' or 'intentional' killing (thus allowing for the legitimacy of 'foreseen but not intended' deaths), Aquinas's version of the prohibition is much stronger and unqualified, and leaves no room for causing the death of innocents by ostensibly 'nonintentional' means. If the death of an innocent person can be foreseen, then an action that causes such a death is lawfully unjustified and falls under the category of culpable homicide.

A key element of Aquinas's philosophy that complements this rejection of foreseen killing of the innocent is his employment of the biblical image of 'the wheat and the tares.' In discussing the legitimacy of killing sinners, Aquinas refers to the parable put forth in Matt. 13:24-30:

24 He put before them another parable: "The kingdom of heaven may be compared to someone who sowed good seed in his field; 25 but while everybody was asleep, an enemy came and sowed weeds among the wheat, and then went away. 26 So when the plants came up and bore grain, then the weeds appeared as well. 27 And the slaves of the householder came and said to him, 'Master, did you not sow good seed in your field? Where, then, did these weeds come from?' 28 He answered, 'An enemy has done this.' The slaves said to him, 'Then do you want us to go and gather them?' 29 But he replied, 'No; for in gathering the weeds you would uproot the wheat along with them. 30 Let both of them grow together until the harvest; and at harvest time I will tell the reapers, Collect the weeds first and bind them in bundles to be burned, but gather the wheat into my barn’” (NRSV translation).

Aquinas comments:

The Lord forbade the uprooting of the weeds in order to preserve the wheat, that is the good. And this applies when the wicked are hidden amongst the good or because they have many followers, so that they cannot be killed without danger to the good, as Augustine says. ${ }^{9}$ This is why the Lord teaches that the wicked are to be allowed to live and to have their punishment deferred until the Last Judgement rather than that the good

\footnotetext{
${ }^{8}$ In his discussion (ST II-II, q.64, a.6) of a judge who knows that an innocent person has been convicted by false witnesses, Aquinas holds that it can in certain limited cases be permissible for the judge to pronounce the person guilty and thus to put that person to death. However, this border-line dilemma, wherein Aquinas holds that the judge is not culpable, involves killing someone who is juridically guilty even though not substantially guilty. By contrast, in a case in which a person is neither juridically guilty nor substantially guilty and is thus innocent in both regards, there would not be a legitimate basis for a public official to engage in killing.

${ }^{9}$ Notably, while Aquinas here refers to Augustine's use, in his Contra Epistolam Parmeniani III.2, of the parable of the wheat and the tares, it is notable that in that context Augustine uses the parable not in connection with the physical killing or non-killing of innocent people in a context of war or criminal punishment, but rather in connection with the exclusion of heretics from the church. Thus, Aquinas puts the parable to a use not found in Augustine, a difference which is also in keeping with the basic contrast between the two that I have drawn here.
} 
should be killed at the same time. Where, however, the good are in no danger but, on the contrary, stand to gain security, the wicked may legitimately be killed (ST II-II, q. 64, a.2). ${ }^{10}$

In making this argument, Aquinas seeks to refute the claim that sinners should never be put to death. In response, he argues that the prohibition on killing sinners holds only when such actions would also involve the unintentional killing of the innocent. If one can kill sinners without killing the innocent, then it is legitimate, given the appropriate authority and circumstances, to kill the sinners. By contrast, if an action that intends to slay the wicked would also result in the innocent being killed, then one must refrain from that initial intended action. In the parable of the wheat and the weeds, the slaves have no intention to cause any harm to the wheat; their intention is simply to destroy the weeds. The harm that would be caused to the wheat would be precisely 'foreseen but not intended.' However, the slaves are told: refrain from your (in principle legitimate) action against the weeds; it is better, in terms of your action, to let the weeds remain than to cause (admittedly non-intended) harm to the wheat. Likewise, Aquinas says, if one has to choose between unintentionally killing the innocent while seeking justly to slay sinners, on the one hand, or refraining from slaying the wicked because doing so would unintentionally kill the innocent, on the other hand, one should choose the latter, even if it means letting the wicked go unpunished for the time being. The wicked will eventually receive their due punishment directly from God, but human beings are not allowed to cause death to the innocent in the attempt to punish the wicked. Again, this reinforces Aquinas's view that public authorities can slay sinners only sake of advancing the common good. However, an action that would knowingly entail the death of the innocent cannot constitute a benefit to the common good. For Aquinas, there is no quantitative weighing involved: a desired action that would entail the foreseen though unintended death of even a single innocent person is forbidden, no matter how many otherwise just and worthwhile aims might be directly intended by the action. Importantly, Aquinas's confidence in the last judgment means that presently forgoing human punishment of evildoers in such circumstances does not entail an abandonment or lessening of the fundamental importance of justice.

Aquinas's application of the parable of the wheat and the tares to the prohibition of killing the wicked when it would also entail causing the death of the innocent can also be understood in connection with his opposition to the notion of collective guilt, wherein punishments can be applied to those who are not guilty in the context an attempt to justly apply punishment to those who are guilty. As I.T. Eschmann has argued, Aquinas held that God can punish a person in temporal matters even if that person has not individually sinned, but that, by contrast, human beings - particularly with regard to punishments of death or bodily harm - can knowingly inflict such harms only to those specific individuals who have been deemed guilty (see Eschmann 1947, 50-55; see also Walters 1971, 161). ${ }^{11}$ As Aquinas states (ST II-II, q. 108, a.4): “[H]uman judgment (judicium humanum) cannot mirror the secret judgments of God that

\footnotetext{
10 See also Aquinas 1975, III, chap. 146, 9, commenting on the same parable of the wheat and the tares: "[T]he execution of the wicked is forbidden wherever it cannot be done without danger to the good.” See also ST II-II, q. 108, a. 1: "When the community as a whole has not sinned, but only a part of it, then it is possible to separate the wicked from the good and make them the object of vengeance. This is true, however, only if it can be done without scandal to the rest; otherwise the whole community is to be spared and severity mitigated”; ST II-II, q. 108, a. 3: "Our Lord forbade the cockle to be uprooted when there was any fear that the wheat would be torn up with it. Sometimes, however, it is possible to get rid of the wicked by death, not only without peril to good people, but even to their great advantage. In such an instance capital punishment can be inflicted upon the wicked.”

${ }^{11}$ For roots of this orientation in biblical conceptuality, see Greenberg 1991, 345-348.
} 
lay earthly penalties upon some people where there is no sin... No man, then, should ever decide that an innocent person be punished by an afflictive punishment, such as death, mutilation, or flogging. As to the punishment of forfeiture, the fact is that some are punished under human sentence even when there has been no offence, but not where there is no cause." Thus, while public authorities can in some cases, if they have good cause, confiscate property from an innocent person, there is no good cause by which human authorities (since they are not God) can justify knowingly or foreseeably causing the death of an innocent person. To be sure, in this context, as with his application of the parable of the wheat and the tares, Aquinas does not explicitly state that this prohibition also applies to the context of war. However, there is also no reason to suppose his generally-stated and forceful pronouncements about human limitations on causing the death of innocents for a 'greater good' would be lessened in the context of human decisions in warfare.

The distinction between human and divine authority also accounts for the unique situation in which, according to Aquinas, human beings can engage in actions that knowingly entail the death of innocents. While I have argued thus far that Aquinas's account allows no room for acts of foreseen though unintended killing of innocents, Aquinas does explicitly state, "God has sovereign authority over life and death, for it is in accordance with his ordinance that both sinners and the just die. Therefore, anyone who kills an innocent person in obedience to God's command commits no sin, since God whose order he is executing commits no sin” (ST IIII, q.64, a. 6). Here, Aquinas states that one can legitimately kill an innocent man - but only if directly commanded by God, who is master of life and death. However, far from contradicting Aquinas's other statements on killing the innocent, this seeming exception actually serves to reinforce the general prohibition. It is only because God has sovereign authority over life and death that a direct command from God can legitimate actions that entail the death of the innocent. By contrast, human beings, who specifically do not possess such sovereign authority over life and death, are much more restricted: in the context of actions that can be legitimated on the basis of 'merely human' judgment and decision, only sinners - and not the innocent - can legitimately be killed, and even then only public authorities have the right to make such judgments. Aquinas, furthermore, saw his present-day context of wars, princes, and public authorizes as operating on the basis of such human judgments, and not on the basis of new divine revelations of the type that commanded Abraham to kill his innocent son Isaac. ${ }^{12}$ Accordingly, there is still no situation in which human beings 'on their own' can legitimately claim that the pursuit of a particular goal of justice and order is 'worth' the unintended yet foreseen death of innocents. In this regard, Aquinas's theological and scriptural orientation looms large: while a 'purely philosophical' approach to justice, order, and the innocent may or may not come to the same conclusions, Aquinas's account seems decisively shaped by specifically biblical and theological concepts and commitments.

Before moving on to the question of Aquinas's treatment of war, we should first pause to consider the ways in which this reading of Aquinas departs from typical received scholarly

\footnotetext{
${ }^{12}$ See Aquinas's contrast between actions carried out on the basis "human law" and the types of divine commands found in the biblical period: "Human law [cannot] permit that a man be lawfully killed when he does not deserve it"; by contrast, "Abraham, in consenting to kill his son, did not consent to homicide, since it was right that his son should be put to death by the command of God, the Lord of life and death. For it is God who inflicts the punishment of death on all men, just as well as unjust, on account of the sin of our first parent; and if man carries out this sentence on the authority of God, he is no murderer any more than God is” (ST I-II, q.100, a. 8). In other words, it is only in the context of God's command and authority, and specifically not under the framework of human judgment and authority, that the just (i.e., those who do not 'deserve it' under human criteria) can be put to death.
} 
understandings. Most notably, having put forth reading that understands the conceptuality of $S T$ II-II, q.64, a.7 as limiting non-intended but legitimate killing only to the case of a private person faced with an immediate aggressor, such that it would not be compatible with private persons or public officials killing an innocent person in a similarly non-intended manner, it is important to note that many contemporary writers in the field of ethics have sought to trace back the legitimacy of such killing of innocents to precisely this passage in Aquinas, in connection with the modern Doctrine of Double Effect. ${ }^{13}$ One frequently finds formulations of the type: just as Aquinas affirmed killing in self-defense through the use of a non-intended effect, so too this same reasoning can be used to justify the non-intended death of innocents - as long as you are intending a just end, knowingly causing the 'additional effect' of the death of innocents through the same action is not inherently forbidden. That is, while acknowledging that Aquinas himself never explicitly applied this reasoning to killing innocents, many thinkers and scholars assume that making such an application can be a legitimate extension of Aquinas's mode of reasoning.

The primary problem with such attempted extensions is that they tend to elide the significance of the specificity of the 'additional effect', whereas for Aquinas not all such effects are morally equivalent. As we saw above in our analysis of ST II-II, q.64, a.6, the life of every human being, qua human being, is by default off-limits to both public officials and private persons, and it is only when a person, by virtue of her transgressive actions, shifts from innocent person to sinner, that causing her death can potentially be legitimate. Because "sin corrodes the common good," the sinner can be killed, but it can never be in accord with the common good to cause the death of an innocent person. Accordingly, because, as regards the human authority to punish, Aquinas strongly individualizes sin and opposes collective guilt, he does not allow for the possibility of causing the death of innocents in an action intended simply to punish evildoers. By contrast, by eliding the significance of the crucial difference between evildoers and innocent people with regard to the common good and with regard to 'killability', many contemporary exponents of the Doctrine of Double Effect treat 'non-intentionally causing the death of innocents in pursuit of a good' as a legitimate extrapolation from Aquinas's affirmation of 'nonintentionally causing the death of a sinner in pursuit of a good.' But, as we have seen, this extrapolation appears not to be legitimate from within the framework of Aquinas's thought. Put differently, if one sets aside Aquinas's distinction between sinner and innocent person, then causing the non-intentional death of innocents could more feasibly be extrapolated from Aquinas's presentation in ST II-II, q.64, a.7, looked at in isolation. ${ }^{14}$ But, if we do not set this distinction aside, then such killing is not a conceptually-compatible derivation from Aquinas's account. For this reason, it is important to keep in mind G.E.M. Anscombe's emphasis on "protesting at the ascription of the Doctrine of Double Effect to Aquinas" (Anscombe 2001, 64). While Aquinas's thought may indeed have certain aspects in common with the modern Doctrine of Double Effect, the functional elision in the latter of the qualitative difference between sinner and innocent in relation to additional-effects marks a major conceptual and historical incompatibility with Aquinas. As Daniel M. Bell has written with regard to such killing of innocents, "[Aquinas] did not permit collateral harm that was foreseen and certain or even likely...This rejection of unintended harm that is foreseen and certain is a prominent feature of

\footnotetext{
${ }^{13}$ For a relevant and thorough treatment of this notion, wherein the prohibition against killing the innocent is understood as applying specifically to 'direct' or 'intentional' killing, see Cavanaugh 2006.

${ }^{14}$ For examples of scholars that provide insightful analyses of this passage vis-à-vis the Doctrine of Double Effect, although still problematically neglecting the sinner/innoncent distinction, see Cavanaugh 2006, 1-14; Reichberg 2005; Matthews 1999.
} 
Aquinas's thought, and yet the principle of double effect developed without regard for it” (Bell 2009, 216). While a few scholarly accounts of Aquinas recognize this difference (see, e.g., Walters 1971, 161; Montaldi 1986, 300, 309, 319, 326-327), in most others it is simply overlooked.

Thus, before moving on to examine the potentially more complicated question of causing the death of innocents in the inter-societal situation of war, let us summarize what appears to be Aquinas's stance for public officials causing the death of innocents in an intra-societal situation. Public officials have the right, in certain circumstances, to take the lives of sinners for the sake of the common good, but the lives of innocent people remain off-limits, as taking their lives can never contribute to the common good. It is thus possible that, in a society, a group of criminals might cause great harm and chaos through their actions, undermining the stability of the society. Their transgressive actions transfer them to the status of sinners, such that their lives can potentially be taken by public officials. If, however, they 'hide themselves amongst the good', so that one cannot kill them without also foreseeably taking the lives of innocents, then the public officials must 'allow the wicked to live', and refrain from engaging in the action that would cause the death of innocents as a foreseen but non-intended side effect. While this refraining from action could, in some cases, mean that the criminals themselves end up causing the deaths of other innocent people, the public officials still cannot act, because their remit for causing the death of human beings, for Aquinas, is strictly limited to the lives of evildoers. Thus, rather than killing the criminals in actions that would take the lives of innocents, the public officials in such an instance would, tragically, have to allow the criminals to continue to kill, with the awareness that God, at the Last Judgment, will be the one to fully set matters aright in accord with true justice. This notion, that public officials, in seeking to prevent crime, are not authorized to cause 'collateral damage' with regard to the lives of innocent citizens within their own societies, is likely less controversial than the idea that causing innocent deaths would also be prohibited in warfare. Thus, before considering whether this stance would or would not also apply to the situation of warfare, we can note that, at the very least, this does indeed seem to be Aquinas's stance with regard to intra-societal killing.

\section{Application to the context of war}

In now turning to the question of warfare, the key question is: do Aquinas's general statements on the illegitimacy of the non-intended killing of the innocent also carry over to the context of warfare? Or, does Aquinas's discussion of warfare contain indications that warfare is somehow different, such that this type of killing would be permissible in warfare? As we have seen, Aquinas is remarkably consistent in upholding his prohibition of killing innocents. While pursuit of the common good, or acts of self-defense, can justify the killing of sinners or aggressors, none of these acts can be pursued if they would simultaneously entail the death of innocents. The overriding element, moreover, lies in the foreseeability of the innocent's death; the agent's intention or non-intention plays no role when the death of the innocent is in question. At the same time, none of the passages from Aquinas discussed thus far explicitly addresses the question of innocent lives in the context of war. As such, it could be conceivable for a philosopher, ethicist, or theologian to say: in general, foreseen yet untended killing of the innocent is prohibited; however, in the case of war, 'things are different', and so the same 
standards do not apply. Here, however, I aim to show that Aquinas's discussion of war does not at all point towards such a stance. It is true that Aquinas never explicitly puts forth a statement like "The foreseen yet unintended death of innocents is prohibited even in war" or "One should refrain from carrying out a military action is it would entail the foreseen yet unintended death of innocents." At the same time, he certainly never indicates that such killing of innocents would be legitimate in the context of war. Therefore, the overarching consistency in his broader treatment of the killing of innocents, combined with the absence of any positive legitimation of the killing of innocents in war, indicates that the most plausible reading of Aquinas is that war, in his view, does not constitute any exception to his general prohibition.

Aquinas compares the use of violence in waging just war to the use of violence in disciplining evildoers within a society. He writes, "And just as [those who are in authority] use the sword in lawful defence against domestic disturbance when they punish criminals,... so they lawfully use the sword of war to protect the commonweal from foreign attacks.” (ST II-II, q.40, a.1). In the case of both domestic and foreign affairs, the public authorities properly have the goal and duty of defending the common good - and, as we have already seen, such a duty provides the authorizes with the right to kill evildoers, but not the right to kill the innocent. Likewise, Aquinas states that, in connection to just cause in war, "those who are attacked are attacked because they deserve it on account of some wrong they have done” (ST II-II, q.40, a.1). Again, this reinforces his general approach in which public officials can rightfully use violence only against those who have committed an offense against the common good. If someone has not committed any blameworthy fault, then such a person cannot legitimately be attacked, and this applies both in the case of violence used against those external to a given society and in the case of violence used against those internal to that society. There is thus a basic continuity in Aquinas's approach to external wrongdoers and to internal wrongdoers; accordingly, just as one is forbidden to engage in otherwise praiseworthy acts of violence against internal evildoers if such acts would entail the death of innocents, so too it would appear that, within Aquinas's framework, it would likewise be forbidden to engage in otherwise praiseworthy acts of violence against external evildoers if such acts would entail the death of innocents. Thus, military actions that might otherwise be just and legitimate would be forbidden if they would involve the foreseeable yet non-intended killing of innocents. There is nothing in Aquinas's discussion of war to indicate that innocents in another society would be subject to greater killability than innocents internal to one's own society. ${ }^{15}$ Given his strong general statements against killing innocents elsewhere, if Aquinas did think that war could constitute an exception, we would have expected him to say so. Since he does not say so, and since he generally presents external evildoers as in continuity with internal evildoers, the most plausible conclusion is that he retains his general restrictions also in the context of warfare.

This conclusion raises the parallel question of precisely who is considered to be an 'innocent' in the context of war. Some thinkers could conceivably agree that it is absolutely prohibited in principle to engage in actions in which the death of innocents is foreseen - while simultaneously asserting that in fact all members of the enemy society are deemed, collectively, to be guilty, so that the prohibition against killing the innocent is simply not relevant to the

\footnotetext{
${ }^{15}$ While Aquinas seems directly to compare war to the use of violence by public authority within a society, some have argued that Aquinas's view of war can best be understood on the analogy to self-defense. See the discussion in Murphy 2012. However, this dispute makes no relevant difference for the point I seek to make here, as one remains prohibited from causing the death of innocents both in the context of self-defense and in the context of just violence used by public authorities.
} 
waging of war against an enemy people. However, although Aquinas does not explicitly pronounce judgment in this regard, it seems plausible to conclude that, because Aquinas maintains a continuity between violence against internal enemies and violence against external enemies, he would also view many individuals within an enemy society as innocent and not as evildoers. In relation to evildoers within one's own society, Aquinas writes, “[I]f those carrying out the orders of a prince or judge attack certain people in the name of public authority and they defend themselves, the former are not guilty of brawling, but rather those who resist public authority. The assailants in this case neither brawl nor commit sin; this applies to those who defend themselves" (ST II-II, q.41, a.1). Here, the servants of those in public authority (i.e., those serving, effectively, as a police force) have the task of apprehending those whom the public authorities have deemed to be evildoers. If the latter 'defend themselves' in order to prevent their apprehension, the public servants have the right to engage in violence against them in order to complete their assigned task. However, in such cases, even if some bystanding civilians are sympathetic to these criminals, it would appear that the public servants could not legitimately kill such sympathizers unless they were actively seeking to step between the public servants and their quarry and to physically obstruct the former from subduing the latter.

Likewise, in the case of a war, soldiers charged by just public officials carry out the task of conquering and subduing the unjust enemy army in order to set aright the common good that has been violated. In this context, the soldiers can engage in violence against the enemy soldiers who seek to prevent them from carrying out their task, even when those enemy soldiers are in one sense simply 'defending themselves' from the just attackers. However, those who are not directly obstructing the just soldiers would, plausibly, remain protected by the prohibition against killing the innocent. While there is certainly room for debate as to what specific types of actions cause a person to cross over from innocent bystander to unjust obstructor of justice, the broader point still holds true, namely, that military actions are prohibited if they would involve the foreseen death of those judged to be innocents.

Given the above argumentation, a question naturally arises about whether Aquinas could realistically have held such a view, as the stance against killing the innocent that I have attributed to Aquinas would appear to place quite heavy restrictions on the waging of just war. Under this stance, any military action that involves foreseen or foreseeable 'collateral damage', causing the death of innocents even in a non-intended manner, would constitute a major and unlawful violation of jus in bello and thus severely compromise the justness of such a war. Yet, since at least in the present, nearly all wars do in fact entail such killing of innocents, could Aquinas really have thought it possible or feasible to engage in warfare under such restrictions? In opposition to my claims here, some could potentially argue that since Aquinas does appear to have affirmed the legitimacy of just war, he must also have affirmed the legitimacy of causing foreseeable but not intended deaths of innocents - otherwise war would in reality be rendered practically impossible to carry out legitimately.

In response to this problem of 'realism', two points should be noted. First, the scope of ethical permissibility needed to make warfare feasible under the conditions of modern and contemporary weapons and modes of military engagement are not necessarily the same as the ethical scope required for feasibly carrying out warfare in the thirteenth century. As LeRoy Walters states in his study of the conditions of warfare in Aquinas's time, “Thirteenth century military practice made possible a rather clear distinction between combatants and noncombatants. Many battles took place in the open field, far from concentrations of civilian population. Combatants were also clearly identified by the fact that they wore armor. Most 
offensive weapons of the period - lances, swords, pikes, and various kinds of bows - could without difficulty be used discriminately" (Walters 1971, 173, and cf. Adeney 1988, 39). In such a context, the ethical requirement of engaging in warfare without causing the death of innocents could indeed have been a practicable restriction. In addition, the idea within the Catholic Church of the 'Peace of God', which declared at least certain classes of non-combatants to be off-limits from killing in war, had already been in existence for a number of centuries prior to Aquinas, and could thus have provided a partial precedent for or influence on his stance (see Russell 1975, 34, 70; and cf. Kinsella 2011, 37-41). To be sure, many wars at the time did in fact entail the death of innocents, particularly when armies engaged in siege of an enemy city (Walters 1971, 173174). But, such practices need not have been seen as essential to warfare, and it would have been possible for a thinker like Aquinas to affirm just war while viewing certain existing military practices as incompatible with the requirements of jus in bello. As Walters argues, Aquinas's consistent opposition to causing the death of innocents, with no exception given for the context of war, can itself be understood as implicitly constituting "a criticism of indiscriminate thirteenth-century military practice” (Walters 1971, 176). As such, given his historical situation, Aquinas's stance does not inherently eliminate the possibility of a just war, although it would place significant restrictions on what would count as legitimate forms of warfare.

In addition, we must bear in mind Aquinas's strong commitment to the notions of divine authority over human life and death, with the concomitant restrictions on human authorization to take life, alongside his commitment to the Last Judgment, which, in the context of the parable wheat and the tares, means that human beings should refrain from pursuing just ends if such ends can be attained only by impermissible means. For Aquinas, the ends do not inherently justify the means, and he does not appear to affirm the pursuit of military victory at all costs. Particularly if thirteenth-century military practices did not seem to render the issue inherent to every instance of warfare, it would be fully in keeping with Aquinas's general stance for him to have thought: if, in the context of a particular military skirmish, the only way to attain victory over the enemy forces is through an action that would also foreseeably cause the death of innocents, one should refrain from 'plucking up the wheat with the tares', even if this means that the enemy army would be victorious in that particular battle. Since he also categorically prohibits uttering falsehoods or breaking promises in the context of warfare (ST II-II , q. 40, a.3) it is plausible that he would likewise uphold his stance on the unlawfulness of causing the death of innocents, even at a cost of military disadvantage.

Thus, while such a stance would indeed have radical implications for just war theory today, Aquinas's thirteenth-century historical setting, alongside his strong theological commitments and his consistently and explicitly stated restrictions on causing the death of innocents, lead to the conclusion that, in terms of a plausible account based on the available textual and historical evidence, this was in fact Aquinas's ethical-legal position. Again, at the very least, if someone did want to argue that Aquinas would have permitted the foreseen but not intended death of innocents in war, the burden of proof would be on such a person to provide evidence from Aquinas's text, and also to give an account of why, in Aquinas's framework, his general prohibition on foreseen but not intended killing would be suspended or inapplicable in the context of war. That is to say, it is certainly possible to posit that Aquinas, due to an unstated sense of 'the realities of war,' held the non-intended killing of innocents in war to be legitimate, but simply did not mention this or give an account of its compatibility with his numerous explicit statements indicating the opposite - however, on the face of it, this does not seem like the most plausible reading of Aquinas's text. 


\section{$\underline{\text { Aquinas’s successors }}$}

I have argued that Aquinas's account entails that unintended yet foreseen killing of the innocent is always prohibited, whether in the case of just war or in the case of evildoers internal to a society. We can further highlight the distinctiveness of Aquinas's position by comparing it to that of those subsequent thinkers who seek to base themselves upon Aquinas, but who depart from Aquinas by removing the categorical prohibition on causing the death of innocents. Instead, they hold that while in most situations and as a general rule innocents should not be killed, it is nevertheless permitted to cause the death of innocents in war in cases of military necessity, so long as the death of the innocents is not directly intended. In other words, they permit the foreseen yet unintended killing of innocents, whereas such actions were unqualifiedly prohibited in Aquinas's framework.

For instance, Cajetan’s (1468-1534) commentary to ST II-II, q.40, a.1 asserts, "[A]ll the losses resulting from a just war...are devoid of sin and entail no duty of restitution on the part of those who inflicted them, even if by accident innocents should happen to be injured...Strictly speaking, one justly receives, even though another innocent person suffers unjustly, for what happens by accident falls outside the rules. It would be otherwise if one acted intentionally to harm the innocent” (Cajetan 2006, 248-249). Here, Cajetan distinguishes between acts that harm the innocent 'intentionally' and acts that harm the innocent 'by accident.' Note that 'by accident' in this context does not appear to mean 'by chance.' That is, 'by accident' here does not seem to mean 'unforeseeable and unintended' but rather 'foreseen or foreseeable, yet unintended.' In other words, for Cajetan, one should not deliberately target innocents in a war, but if innocents are harmed, even with foreknowledge, through the prosecuting of an otherwise just war, then such actions are "devoid of sin." 16 This position departs sharply from Aquinas, who makes no such assertions about permitted harm to innocents in his treatment of war, and whose general position, as we have seen, asserts that one who causes the death of innocents in a foreseen yet unintended manner "is guilty of any homicide that may occur."

Francisco de Vitoria (1483-1586) indicates a marked concern for protection of the innocent, stating, in terms that appear to be directly drawing upon Aquinas, "[I]t is never lawful in itself intentionally to kill innocent people” (Vitoria 1991, 314). However, while Vitoria’s assertion of 'never' seems quite categorical, we can already note the subtle insertion of 'intentionally', which is not found in Aquinas's discussion of causing the death of innocents, and which, for Vitoria, opens up space for justifying the death of innocents. He thus goes on to assert, "It is occasionally lawful to kill the innocent not by mistake, but with full knowledge of what one is doing, if this is an accidental effect: for example, during the justified storming of a fortress or city, where one knows there are many innocent people, but where it is impossible to fire artillery or other projectiles or set fire to buildings without crushing or innocent along with the combatants" (Vitoria 1991, 315). Such a statement represents a very articulate exposition of the principle that continues to be employed in contemporary discourse: causing the death of innocents (as distinguished from combatants) with full foreknowledge, not as a desired end, but rather as an "accidental effect" of an otherwise justified military action. Again, however, it is precisely on this issue that Vitoria departs from Aquinas, who held that causing death of

\footnotetext{
${ }^{16}$ See Mangan 1949, 52-54: "Cajetan seems to be the first to apply the principle of the double effect explicitly to the killing of innocent people."
} 
innocents with foreknowledge is forbidden, and did not make any exceptions for the conduct of war.

Notably, even in this major departure, we can still view Vitoria as strongly attempting to align himself with Aquinas's previous precedent. Vitoria writes, "[I]t is never lawful to kill innocent people, even accidentally and unintentionally, except when it advances a just war which cannot be won in any other way. In the words of the parable, 'Let the tares grow until the harvest, lest while ye gather up the tares, ye root up also the wheat with them' (Matt. 13:24-30)" (Vitoria 1991, 316). As we have seen, Aquinas highlighted the same parable in insisting that one 'allow the wicked to live', rather than cause the death of innocents, and to instead have faith in the punishment of the wicked at the Last Judgment, i.e., 'the harvest'. Yet, unlike Aquinas, Vitoria, while drawing on the parable, seems to undermine its basic meaning. While the parable itself requires the servants, in an unqualified manner, to 'let the tares grow' rather than unintentionally uprooting the wheat, Vitoria instead functionally renders it as: in general, you should not uproot the wheat, even accidentally, in attempting to gather up the tares - unless uprooting the tares cannot be achieved in any other way, in which case you can go ahead and let the wheat be uprooted!

Importantly, Vitoria reasons that causing the death of innocents in such instances must be lawful, "since it would be otherwise impossible to wage war against the guilty, thereby preventing the just side from fighting" (Vitoria 1991, 315). In other words, while he generally wants to follow in the footsteps of Aquinas and to grant great weight to the prohibition against killing the innocent, he nevertheless operates with a different ethical priority than Aquinas. Under Vitoria's understanding of the attempts of the 'just side' to protect the common weal against evildoers, innocents can be sacrificed for this greater good (cf. Walters 1971, 364, 385). In other words, although great weight is placed both on the negative obligation of refraining from killing the innocent and on the positive obligation of punishing evildoers and upholding public order, when these two obligations conflict, the latter takes priority. By contrast, for Aquinas, the priority is reversed. Again, it is possible to sympathize with Vitoria's 'realist' intuition that an unqualified prohibition on killing the innocent might indeed make many instances of successful warfare "impossible," but it remains the case that for Aquinas no action that foreknowingly entails the death of innocents can be considered just in the first place. We can thus view Vitoria's significant qualification of 'intentionally' to the prohibition of killing the innocent as his attempt to uphold Aquinas's basic language and formulations, while in substance diverging sharply from Aquinas's theologically influenced and unqualified position. If Vitoria could have found a way of grounding his position through a direct citation of Aquinas himself, he assuredly would have done so, but in actual fact there is no conceptual or textual basis in Aquinas for justifying the stance that Vitoria desires to put forth.

\section{Conclusion}

Subsequent inheritors of the just war tradition continued in the basic path of Vitoria: while often showing concern for the lives of innocents as a general principle, they nevertheless affirm that it is legitimate to kill innocents in war, so long as such actions are militarily necessary and so long as the agents do not directly intend the death of those innocents who are killed. ${ }^{17}$ In this, they may be seen as functionally aligning with Augustine's stance, which combines love

\footnotetext{
${ }^{17}$ See Hartigan 1982, 93ff, for discussion of the way in which Suárez, Grotius, and subsequent thinkers follow Vitoria's basic approach in this regard.
} 
and concern for the innocent with a duty of upholding the public order, but ultimately prioritizes the latter over the former. As such, in the Christian just war tradition from Augustine onward, Aquinas appears to hold a unique position in comparison both to his predecessors and to his successors - while not a pacifist, and while affirming the legitimacy of war, he holds that innocents cannot be killed in the attempt to carry out actions that would otherwise be just and proper, and he does not appear to treat war as constituting an exception to this rule. That is to say, he differs both from those who affirm an unqualified prohibition of killing innocents but who do so in the context of a pacifist stance, and from those who take a 'just war' position but who allow for the non-intentional killing of innocents. ${ }^{18}$

Owing to his distinctive position, scholarly accounts that assume a general historical continuity in the Christian just war tradition have often assumed Aquinas's stance on killing the innocent to be basically compatible with that of Augustine and of the post-Aquinas thinkers. However, it may in fact be the case that Aquinas represents a significant discontinuity within the tradition. It is not merely that he does not actively or explicitly affirm the non-intentional killing of the innocent in war, but that his fundamental ethical principles would reject such killing as profoundly unjust. As such, many contemporary accounts of Aquinas vis-à-vis the just war tradition constitute a fundamental distortion of his position. A recovery of Aquinas's position, by contrast, would not only represent a desirable scholarly-historical correction, but would also provide new resources to current ethical, philosophical, and theological debates over the legitimacy of causing the death of innocents in war. Given Aquinas's weighty status and influence, reassessment of his thought in this regard has the possibility to reorient and shake up entrenched conceptual divisions between 'just war' and 'pacifist' approaches.

\footnotetext{
${ }^{18}$ Some recent approaches to war that come close to Aquinas's position on killing the innocent (in practical, though not theological terms) include Fiala 2008, 170; Holmes 1989, 183-213. Notably, however, in detailing these approaches, these authors do not recognize Aquinas as a key precursor in this regard.
} 
Adeney, Bernard

$1988 \quad$ Just War, Political Realism, and Faith. Metuchen, NJ: ATLA.

Anscombe, G.E.M.

2001 [1982] “Medalist's Address: Action, Intention, and 'Double Effect.”' In The Doctrine of Double Effect: Philosophers Debate a Controversial Moral Principle, edited by P.A. Woodward, 50-66. Notre Dame, IN: University of Notre Dame Press.

Aquinas, Thomas

1964-1980 Summa Theologiae. Translated by Thomas Gilby et al. London and New York:

Blackfriars.

1975 Summa Contra Gentiles. Translated by Vernon J. Bourke. Notre Dame and London: University of Notre Dame Press.

Augustine

1994 [1887] “Reply to Faustus the Manichaen.” In Nicene and Post-Nicene Fathers, First

Series, Volume Four, edited by Phillip Schaff. Peadbody, MA: Hendrickson, 1994.

Bell, Daniel M., Jr.

$2009 \quad$ Just War as Christian Discipleship: Recentering the Tradition in the Church rather than the State. Grand Rapids, MI: Brazos Press.

Cajetan

2006 "War and Vindicative Justice" [Commentary to ST II-II, q.40, a.1]. In The Ethics of War: Classic and Contemporary Readings, edited by Gregory M. Reichberg, Henrik Syse, Endre Begby, 240-250. Malden, MA: Wiley-Blackwell.

Cavanaugh, T.A.

2006 Double-Effect Reasoning: Doing Good and Avoiding Evil. Oxford: Oxford

University Press.

Cooper, John M.

2013 “Aristotelian Responsibility.” In Oxford Studies in Ancient Philosophy, Volume 45, edited by Brad Inwood, 265-312. Oxford: Oxford University Press.

Eschmann, I.T.

1947 "Studies on the Notion of Society in St. Thomas Aquinas II: Thomistic Social Philosophy and the Theology of Original Sin.” Mediaeval Studies 9.1:19-55.

Fiala, Andrew

2008 The Just War Myth: The Moral Illusions of War. Lanham, MD: Roman \& Littlefield.

Greenberg, Moshe 
1991 “Some Postulates of Biblical Criminal Law” [1960]. In Essential Papers on Israel and the Ancient Near East, edited by Frederick E. Greenspahn, 333-352. New York: NYU Press.

Hartigan, Richard S.

1966 "Saint Augustine on War and Killing: The Problem of the Innocent." Journal of the History of Ideas, 27.2: 195-204

1982 The Forgotten Victim: A History of the Civilian. Chicago, IL: Precedent.

Holmes, Robert L.

1989 On War and Morality. Princeton: Princeton University Press.

Kinsella, Helen M.

2011 The Image Before the Weapon: A Critical History of the Distinction between Combatant and Civilian. Ithaca: Cornell University Press.

Mangan, Joseph

1949 "An Historical Analysis of the Principle of Double Effect.” Theological Studies 10: 41-61.

Matthews, Gareth B.

1999 "Saint Thomas and the Principle of Double Effect." In Aquinas's Moral Theory, edited by Scott MacDonald and Eleonore Stump. Ithaca, NY: Cornell University Press.

Montaldi, Daniel F.

1986 “A Defense of St. Thomas and the Principle of Double Effect.” The Journal of Religious Ethics , 14.2: 296-332.

Murphy, James Bernard

2012 "Suárez, Aquinas, and the Just War: Self Defense or Punishment?” In From Just War to Modern Peace Ethics, edited by Heinz-Gerhard Justenhoven and William A. Barbieri, Jr., 175-196. Berlin and Boston: De Gruyter.

Ramsey, Paul

$1961 \quad$ War and the Christian Conscience: How Shall Modern War Be Conducted Justly? Durham, NC: Duke University Press.

2002 [1968] The Just War: Force and Political Responsibility. Lanham, MD: Rowman \& Littlefield.

Reichberg, Gregory M.

2005 “Aquinas on Defensive Killing: A Case of Double Effect?” The Thomist 69: 34170. 
Russell, Frederick H.

1975 The Just War in the Middle Ages. Cambridge: Cambridge University Press.

Stevenson, William R.

1987 Christian Love and Just War: Moral Paradox and Political Life in St. Augustine and His Modern Interpreters. Macon, GA: Mercer University Press.

Vitoria, Francisco de

$1991 \quad$ Political Writings. Edited by Anthony Pagden and Jeremy Lawrance. Cambridge: Cambridge University Press.

Walters, LeRoy.

1971 Five Classic Just-War Theories: A Study in the Thought of Thomas Aquinas, Vitoria, Suarez, Gentili, and Grotius. Ph.D. dissertation, Yale University. 